\title{
Self-Reported Effectiveness of e-Learning Classes during COVID-19 Pandemic: A Nation-Wide Survey of Pakistani Undergraduate Dentistry Students
}

\author{
Huma Sarwar ${ }^{1}$ Hira Akhtar ${ }^{2} \quad$ Meshal Muhammad Naeem ${ }^{3} \quad$ Javeria Ali Khan ${ }^{4} \quad$ Khadija Waraich $^{1}$ \\ Sumaiya Shabbir ${ }^{1}$ Arshad Hasan ${ }^{4, \odot ~ Z o h a i b ~ K h u r s h i d ~}{ }^{5, \odot}$
}

\author{
${ }^{1}$ Department of Operative Dentistry, Dr. Ishrat-UI-Ibad Khan \\ Institute of Oral Health Sciences, Dow University of Health \\ Sciences, Karachi, Pakistan \\ 2Department of Pediatric Dentistry, Dow Dental College, \\ Dow University of Health Sciences, Karachi, Pakistan \\ ${ }^{3}$ Department of Periodontology, Dr. Ishrat-Ul-Ibad Khan Institute of \\ Oral Health Sciences, Dow University of Health Sciences, Karachi, \\ Pakistan \\ ${ }^{4}$ Department of Operative Dentistry, Dow Dental College, \\ Dow University of Health Sciences, Karachi, Pakistan \\ ${ }^{5}$ Department of Prosthodontics and Dental Implantology, College \\ of Dentistry, King Faisal University, Al Ahsa, Saudi Arabia
}

\begin{abstract}
Address for correspondence Arshad Hasan, BDS, FCPS, Department of Operative Dentistry, Dow Dental College, Dow University of Health Sciences, Karachi 74200, Pakistan (e-mail: arshad.hasan@duhs.edu.pk).
\end{abstract}

\begin{abstract}
Keywords

- dental students

- e-learning

- COVID-19

- dentistry

- online teaching

- dental education

Objectives The main aim of this study was to determine the undergraduate dental students' self-reported effectiveness of online classes offered by various dental institutes of Pakistan.

Materials and Methods A cross-sectional study was conducted using an online survey. A pretested and validated questionnaire comprising of 31 questions was circulated among dental students. The study participants were inquired about the perceived level of accessibility of resources and the effectiveness of online teaching. The data was analyzed using SPSS version 24. Mann-Whitney $U$ test and Kruskal-Wallis test were used for statistical analysis at $p \leq 0.05$.

Results A total of 1,207 students from all over Pakistan responded. The majority of students was dissatisfied with the institutional learning management system and quality of learning resources available. Students were also dissatisfied with the level of training of teachers for online lectures. The worst rating was reported for questions related to the effectiveness of online classes (average rating: 3.83 and 3.781/5). First-year students reported poor interaction with teachers $(p<0.001)$ and strongly disagreed with the effectiveness of online classes (mean rating: $4.14 \pm 0.935$ ).

Conclusions The results from the present survey showed that dental students of Pakistan unanimously voiced dissatisfaction toward various elements of online teaching sessions. Findings from this survey will aid the academic institutes to establish proficient learning platforms focused on improving students` learning experience.
\end{abstract}

DOI https://doi.org/

10.1055/s-0040-1717000 ISSN 1305-7456.
(C) 2020. European Journal of Dentistry.

This is an open access article published by Thieme under the terms of the Creative Commons Attribution-NonDerivative-NonCommercial-License, permitting copying and reproduction so long as the original work is given appropriate credit. Contents may not be used for commercial purposes, or adapted, remixed, transformed or built upon. (https://creativecommons.org/licenses/by-nc-nd/4.0/)

Thieme Medical and Scientific Publishers Pvt. Ltd., A-12, 2nd Floor, Sector 2, Noida-201301 UP, India 


\section{Introduction}

The current coronavirus disease 2019 (COVID-19) pandemic has forced the world into a standstill. To prevent the spread of disease, countries all over the world have adopted social-distancing policies. This has limited the movement of people, disrupted their daily activities, and instituted work-from-home strategy for all employment sectors. The COVID-19 climate has devastatingly impacted global education as well. Educational institutes all over the world are forced to rapidly shift from the traditional style of teaching to an online learning format. The academic institutes of Pakistan are no exception to this global pedagogical revolution. ${ }^{1}$

In the current quarantine, online mode of learning has become a viable academic alternative to conventional teaching techniques owing to vast improvements in the field of information technology. ${ }^{2}$ The existing dental curriculum implores students to master a broad spectrum of professional elements such as sound theoretical knowledge alongside robust clinical and interpersonal skills. ${ }^{3}$ This extremely complex dental curriculum requires continuous review, revision, and updating to remain effective. ${ }^{4}$ Even though online learning offers limitless potential in relations to improving teaching dynamics; universities find incorporating both theoretical and clinical components of dental education into an online format challenging. ${ }^{5}$ Purely for the benefits of pedagogical advancements, learning management system (LMS) has been around in use in various countries around the world. But it is met with its fair share of hurdles. Acceptance of LMS is still questionable, as apparent in a study conducted by Alghamdi and Bayaga, which demonstrated an absolute lack of technical skills among the older generation to reap its full benefits. ${ }^{6}$ Many universities and educational institutes in Saudi Arabia are yet to adapt LMS as a permanent feature in various teaching activities. ${ }^{7}$ This, in turn, foreshadows the true purpose of the usage of LMS, which is to enhance the various modalities of teaching effectiveness and learning for the young generation.

The success of an online teaching program can be evaluated by measuring a student's perception of virtual learning. ${ }^{8}$ A plethora of international data are available on dental students' perception of different online teaching modalities.9-12 Studies have reported diverse student responses ranging from complete acceptance of online sessions over conventional teaching methods to absolute dissatisfaction toward e-learning. ${ }^{13-15}$ Advancements in technology coupled with the increasing number of students in classes requiring increase in teachers and required classroom spaces, a concept of "blended learning," has been introduced for medical teaching. ${ }^{16}$ As medicine has a prominent and crucial practical domain, blended learning couples face-to-face learning with online teaching modalities combined in e-learning modules. ${ }^{15,17}$ This allows the individual student to learn in group dynamics and also by themselves at their own pace and timing suitable for them, which is demonstrative of the student-centered learning.

Before coronavirus pandemic, online education in Pakistan had a limited existence. After the 2019 pandemic lockdown, the academic institutions, including dental universities of Pakistan, were faced with a mammoth task to establish an online teaching forum matching the productivity and effectiveness of customary face-to-face teaching regime. The intricacies of the dental curriculum may present a hurdle in successfully transforming and converting a previously efficacious mode of conventional learning into an online teaching platform of equal potency. There is a lack of national research data available regarding the effectiveness of online teaching among dental undergraduate students of Pakistan. ${ }^{18}$ Ahmed et al reported that dentists around the globe are in the state of constant fear and anxiety due to COVID-19 pandemic. To alleviate this anxiety, practice modification along with continuous educational session through e-learning, infection control workshops, and some fear reduction psychological sessions for extremely anxious dental staff by a team of trained psychologists were recommended. ${ }^{19}$

To fulfil this research gap, the current nation-wide survey-based study was designed with the objectives to assess the perception of dental students regarding the effectiveness of online teaching in Pakistan and highlight the challenges faced by them in adjusting to this new mode of learning.

\section{Materials and Methods}

This cross-sectional study was conducted in the dental colleges of Pakistan. In Pakistan, the dental institutes pursue a 4-year undergraduate dentistry program followed by 1 year of mandatory house job before receiving their license to practice. Therefore, undergraduate dental students, from the first year to final (4th) year, who attended online classes, were included in this study. Students who declined to consent, house officers, and students of allied specialties were excluded from this study. Purposive sampling was done for sample recruitment. A pretested and validated questionnaire, comprising of 31 questions, was used.

The questionnaire was made by using Google Docs (www.docs.google.com). The form was circulated among dental students of Pakistan through social media and e-mail. This questionnaire was not based on any previous study and was developed from scratch. Pretesting phase involved testing of the questionnaire by a sample of undergraduate students from all 4 years. Cronbach's Alpha was used to determine the internal consistency of the questionnaire. The value was 0.785 , which indicated an acceptable level of internal consistency. The sample size for the study was calculated by using an open-epi online calculator. A 59.2\% response reported by Asiry ${ }^{13}$ was used at a 95\% confidence level. A sample size of 371 participants was calculated. The survey was divided into three sections. In the first section, the study participants were asked about their demographic details and year of study. In the second section of the survey, the students were inquired about the quality of technological resources and general questions about online teaching. A five-point Likert scale was 
Table 1 Basic demographics of study participants $(n=1,207)$

\begin{tabular}{|c|c|c|}
\hline Characteristics & & Mean \pm SD \\
\hline \multirow[t]{3}{*}{ Age } & & $20.74 \pm 1.55$ \\
\hline & Min & 16 \\
\hline & Max & 31 \\
\hline \multirow[t]{3}{*}{ Gender } & & $n(\%)$ \\
\hline & Male & 331 (27.4) \\
\hline & Female & 876 (72.6) \\
\hline \multicolumn{3}{|l|}{ Institution } \\
\hline & Public sector & 427 (35.4) \\
\hline & Private sector & 780 (64.6) \\
\hline \multicolumn{3}{|l|}{$\begin{array}{l}\text { Year of Undergraduate } \\
\text { BDS Study }\end{array}$} \\
\hline & First-year & $253(21.0)$ \\
\hline & Second-year & 372 (30.8) \\
\hline & Third-year & 221 (18.3) \\
\hline & Fourth-year & 361 (29.9) \\
\hline \multicolumn{3}{|l|}{ Province } \\
\hline & Sindh & $844(70.0)$ \\
\hline & Punjab & 277 (22.9) \\
\hline & $\begin{array}{l}\text { Khyber } \\
\text { Pakhtunkhwa (KPK) }\end{array}$ & $70(5.8)$ \\
\hline & Balochistan & $16(1.3)$ \\
\hline
\end{tabular}

used in the third section of the survey to assess students' self-perceived effectiveness of online classes.

\section{Statistical Analysis}

Data were analyzed by using SPSS version 24.0. Descriptive statistics for age was reported as mean and standard deviation, while frequencies and percentages were reported for all categorical characteristics (-Tables 1-3). Mann-Whitney $U$ test was used to examine the differences in the parameters of the effectiveness of online education between public and private sector groups ( $\mathbf{- T a b l e ~} \mathbf{4}$ ). The Kruskal-Wallis test was used to investigate the associations of characteristics like major geographic regions (provinces) of Pakistan and year of study with the parameters of effectiveness of online education ( $\mathbf{- T a b l e s} \mathbf{5}$ and $\mathbf{6}$ ). A value of $p \leq 0.05$ was considered significant.

\section{Results}

This online survey was conducted using Google Docs and a reasonably large sample size of 1,207 participants from across Pakistan responded. - Table 1 represents the basic demographics of the study population.

More students at private sector institutes participated in the survey as compared with public sector educational
Table 2 Technology readiness of the study participants $(n=1,207)$

\begin{tabular}{|c|c|c|}
\hline & & $n(\%)$ \\
\hline \multicolumn{3}{|c|}{ Do you have easy access to the Internet? } \\
\hline & Yes & $1,030(85.3)$ \\
\hline & No & $117(14.7)$ \\
\hline \multicolumn{3}{|c|}{$\begin{array}{l}\text { If yes, how would you grade your internet connectivity? } \\
\text { ( } 1=\text { poor to } 5=\text { excellent) }\end{array}$} \\
\hline & 1 & $25(2.4)$ \\
\hline & 2 & $101(9.8)$ \\
\hline & 3 & $403(39.1)$ \\
\hline & 4 & $388(37.7)$ \\
\hline & 5 & $113(11.0)$ \\
\hline \multicolumn{3}{|c|}{ Do you have an unimpeded electrical supply? } \\
\hline & Yes & $672(55.7)$ \\
\hline & No & $535(44.3)$ \\
\hline \multicolumn{3}{|c|}{ Which of the following device do you use for online classes } \\
\hline & Smartphone & $760(63.0)$ \\
\hline & Laptop & 397 (32.9) \\
\hline & Tablet & $37(3.1)$ \\
\hline & Desktop & $13(1.0)$ \\
\hline & Other & 0 \\
\hline \multicolumn{3}{|c|}{ What is the mode of notification of class schedule? } \\
\hline & Via email & $357(29.6)$ \\
\hline & Via individual text on cell phone & $27(2.2)$ \\
\hline & $\begin{array}{l}\text { Though social media, e.g., } \\
\text { WhatsApp or Facebook }\end{array}$ & $712(59.0)$ \\
\hline & Through an institution Web site & $78(6.5)$ \\
\hline & Other & $33(2.7)$ \\
\hline
\end{tabular}

institutes. According to the year of study, there were 253 (21.0) first-year, 372 (30.8) second year, 221 (18.3) thirdyear, and 361 (29.9) fourth-year students. Distribution of students according to major geographic regions (provinces) of Pakistan is as follows: Sindh, 844 (70.0); Punjab, 277 (29.9); Khyber Pakhtunkhwa (KPK), 70 (5.8); and Balochistan, 16 (1.3).

\section{Technology Readiness of Study Participants}

Majority of the students reported some form of access to the internet ( $n=1010,85.3 \%$ ). However, more than half (51.3\%) rated their internet connection as poor to average quality. While less than half $(48.7 \%)$ rated the quality of their connection to be excellent or good as described in - Table 2, 55.7\% participants reported uninterrupted electrical supply; however, this figure might drastically change as the country enters summer season, and electricity demand exceeds the supply. Smartphone $(n=760,63 \%)$ and laptop ( $n=397,39.2 \%$ ) were the most preferred devices of 
Self-Reported Effectiveness of e-Learning Classes during COVID-19 Pandemic Sarwar et al. S37

Table 3 Effectiveness of online classes

\begin{tabular}{|c|c|c|c|c|c|c|}
\hline & $\begin{array}{l}\text { Strongly } \\
\text { agree, } n \text { (\%) }\end{array}$ & Agree, $n(\%)$ & Neutral, $n$ (\%) & Disagree, $n$ (\%) & $\begin{array}{l}\text { Strongly } \\
\text { disagree, } n(\%)\end{array}$ & $\begin{array}{l}\text { Rating } \\
\text { average, } n(\%)\end{array}$ \\
\hline $\begin{array}{l}\text { 1. My institution has } \\
\text { an online learning } \\
\text { management system } \\
\text { (LMS) or Web site } \\
\text { where all information } \\
\text { about online classes is } \\
\text { available }\end{array}$ & $113(9.4)$ & $446(37.0)$ & $298(24.7)$ & $219(18.1)$ & $131(10.9)$ & 2.84 \\
\hline $\begin{array}{l}\text { 2. All key information } \\
\text { about the course is } \\
\text { available on LMS or } \\
\text { institution Web site }\end{array}$ & $77(6.4)$ & $367(30.4)$ & 313 (25.9) & $299(24.8)$ & $151(12.5)$ & 3.07 \\
\hline $\begin{array}{l}\text { 3. All course readings, } \\
\text { assignments and } \\
\text { lectures are available } \\
\text { online }\end{array}$ & $104(8.6)$ & $413(34.2)$ & $265(22.0)$ & 259 (21.5) & $168(13.8)$ & 2.98 \\
\hline $\begin{array}{l}\text { 4. Students are assisted } \\
\text { in overcoming } \\
\text { obstacles in access- } \\
\text { ing the classes or } \\
\text { materials }\end{array}$ & $63(5.2)$ & $427(35.4)$ & 392 (32.5) & $227(18.8)$ & $98(8.1)$ & 2.89 \\
\hline $\begin{array}{l}\text { 5. Time allotted for } \\
\text { online classes is } \\
\text { sufficient? }\end{array}$ & $168(13.9)$ & $655(54.3)$ & $214(17.7)$ & $121(10.0)$ & $49(4.1)$ & 2.36 \\
\hline $\begin{array}{l}\text { 6. I am able to interact } \\
\text { with teachers during } \\
\text { online classes }\end{array}$ & $158(13.1)$ & $495(41.0)$ & 249 (20.6) & $191(15.8)$ & $114(9.4)$ & 2.68 \\
\hline $\begin{array}{l}\text { 7. I am able to interact } \\
\text { with teachers after } \\
\text { online class in the } \\
\text { Q\&A session }\end{array}$ & $162(13.4)$ & $615(51.0)$ & $230(19.1)$ & $144(11.9)$ & $56(4.6)$ & 2.43 \\
\hline $\begin{array}{l}\text { 8. Every individual is } \\
\text { given a chance to } \\
\text { participate and pitch } \\
\text { in their ideas during } \\
\text { online classes }\end{array}$ & $122(10.1)$ & $535(44.3)$ & $215(17.8)$ & $213(17.6)$ & $122(10.1)$ & 2.73 \\
\hline $\begin{array}{l}\text { 9. The teachers are well } \\
\text { trained for online } \\
\text { classes and are able } \\
\text { to use the Video } \\
\text { Conferencing App } \\
\text { with ease }\end{array}$ & $110(9.1)$ & $330(27.3)$ & $343(28.4)$ & 289 (23.9) & $135(11.2)$ & 3.01 \\
\hline $\begin{array}{l}\text { 10. Attending classes } \\
\text { from home hampers } \\
\text { my attention and } \\
\text { focus }\end{array}$ & 252 (20.9) & $399(33.1)$ & $271(22.5)$ & 200 (16.6) & $85(7.0)$ & 2.56 \\
\hline $\begin{array}{l}\text { 11. Online classes are } \\
\text { equally or more } \\
\text { informative as } \\
\text { compared with active } \\
\text { learning in campus }\end{array}$ & $64(5.3)$ & $129(10.7)$ & $179(14.8)$ & $414(34.3)$ & $421(34.9)$ & 3.83 \\
\hline $\begin{array}{l}\text { 12. Online learning fits in } \\
\text { my schedules better } \\
\text { than normal day to } \\
\text { day classes }\end{array}$ & $91(7.5)$ & $229(19.0)$ & $237(19.6)$ & $375(31.1)$ & $275(22.8)$ & 3.43 \\
\hline
\end{tabular}

(continued)

the students for accessing online classes. Social media was the most preferred media for notification of class schedules.

\section{Effectiveness of Online Classes}

A five-point Likert scale (Strongly agree $=1$, agree $=2$, neutral $=3$, disagree $=4$, strongly disagree $=5$ ) was used for assessing the overall effectiveness of online classes, as presented in $\boldsymbol{-}$ Table $\mathbf{3}$. The students were not only dis-satisfied with the institutional LMS and quality of learning resources available, but also with the level of training of teachers for online lectures (average rating: 3.01). The worst rating was reported for questions; online classes are equally or more informative as compared with active learning in campus (average rating: 3.83 ), and I would like to have these online sessions continued even after campus classes have started (average rating: 3.78). 
Table 3 (continued)

\begin{tabular}{|c|c|c|c|c|c|c|}
\hline & $\begin{array}{l}\text { Strongly } \\
\text { agree, } n(\%)\end{array}$ & Agree, $n$ (\%) & Neutral, $n(\%)$ & Disagree, $n$ (\%) & $\begin{array}{l}\text { Strongly } \\
\text { disagree, } n \text { (\%) }\end{array}$ & $\begin{array}{l}\text { Rating } \\
\text { average, } n(\%)\end{array}$ \\
\hline $\begin{array}{l}\text { 13. Demonstration } \\
\text { of clinical/labora- } \\
\text { tory work by the } \\
\text { instructor during } \\
\text { online classes } \\
\text { would help me } \\
\text { learn in a better } \\
\text { way }\end{array}$ & $114(9.4)$ & $247(20.5)$ & $196(16.2)$ & $342(28.3)$ & 308 (25.5) & 3.40 \\
\hline $\begin{array}{l}\text { 14. I would like to } \\
\text { have these online } \\
\text { sessions continued } \\
\text { even after campus } \\
\text { classes have } \\
\text { started }\end{array}$ & $68(5.6)$ & $164(13.6)$ & $171(14.2)$ & $365(30.2)$ & $439(36.4)$ & 3.78 \\
\hline
\end{tabular}

Table 4 Comparison of public and private sector colleges $(n=1,207)$

\begin{tabular}{|c|c|c|c|}
\hline & $\begin{array}{l}\text { Public } \\
\text { sector, } n=427\end{array}$ & $\begin{array}{l}\text { Private sector, } \\
n=780\end{array}$ & p-Value \\
\hline & Mean \pm SD & Mean \pm SD & \\
\hline $\begin{array}{l}\text { My institution has an online learning management system (LMS) or Web site where all } \\
\text { information about online classes is available }\end{array}$ & $3.19 \pm 1.14$ & $2.65 \pm 1.12$ & $<0.001^{\mathrm{a}}$ \\
\hline All key information about the course is available on the LMS or institution Web site & $3.39 \pm 1.11$ & $2.88 \pm 1.12$ & $<0.001^{\text {a }}$ \\
\hline All course readings, assignments, and lectures are available online & $3.53 \pm 1.17$ & $2.67 \pm 1.11$ & $<0.001^{\mathrm{a}}$ \\
\hline Students are assisted in overcoming obstacles in accessing the classes or materials & $3.14 \pm 1.06$ & $2.75 \pm 0.99$ & $<0.001^{\mathrm{a}}$ \\
\hline Time allotted for online classes is sufficient? & $2.44 \pm 1.01$ & $2.31 \pm 0.96$ & 0.054 \\
\hline I am able to interact with teachers during online classes & $3.06 \pm 1.16$ & $2.46 \pm 1.12$ & $<0.001^{\mathrm{a}}$ \\
\hline I am able to interact with teachers after online class in the Q\&A session & $2.44 \pm 0.97$ & $2.43 \pm 1.04$ & 0.496 \\
\hline $\begin{array}{l}\text { Every individual is given a chance to participate and pitch in their ideas during online } \\
\text { classes }\end{array}$ & $3.13 \pm 1.22$ & $2.51 \pm 1.08$ & $<0.001^{\text {a }}$ \\
\hline $\begin{array}{l}\text { The teachers are well trained for online classes and are able to use the Video } \\
\text { Conferencing App with ease }\end{array}$ & $3.31 \pm 1.11$ & $2.84 \pm 1.14$ & $<0.001^{\mathrm{a}}$ \\
\hline Attending classes from home hampers my attention and focus & $2.46 \pm 1.17$ & $2.6 \pm 1.20$ & 0.094 \\
\hline $\begin{array}{l}\text { Online classes are equally or more informative as compared with active learning in } \\
\text { campus }\end{array}$ & $3.97 \pm 1.08$ & $3.74 \pm 1.21$ & $<0.01^{\mathrm{a}}$ \\
\hline Online learning fits in my schedules better than normal day to day classes & $3.41 \pm 1.21$ & $3.43 \pm 1.26$ & 0.589 \\
\hline $\begin{array}{l}\text { Demonstration of clinical/laboratory work by the instructor during online classes } \\
\text { would help me learn in a better way }\end{array}$ & $3.38 \pm 1.30$ & $3.41 \pm 1.32$ & 0.672 \\
\hline $\begin{array}{l}\text { I would like to have these online sessions continued even after campus classes have } \\
\text { started }\end{array}$ & $3.92 \pm 1.14$ & $3.70 \pm 1.27$ & $<0.01^{\text {a }}$ \\
\hline
\end{tabular}

Abbreviation: SD, standard deviation.

${ }^{a} p$-Value calculated by using Mann-Whitney $\mathrm{U}$ test.

\section{Comparison of Public and Private Sector Colleges}

This critical comparison revealed a significant disparity between the satisfactions of students from public versus private sector colleges. - Table 4 represents a comparison of Likert responses with the type of dental institute using Mann-Whitney $U$ test. The public sector students were not satisfied with various attributes of LMS $(3.53 \pm 1.17$, $p<0.001$ ), assistance received in overcoming difficulties
(3.14 $\pm 1.06, p<0.001)$, ability to interact with teachers (3.06 $\pm 1.16, p<0.001)$, and whether the teachers are trained for online teaching $(3.31 \pm 1.11, p<0.001)$.

\section{Comparison of Major Geographic Regions (Provinces) of Pakistan}

Stratification of our data into the provinces that make up major geographic regions of Pakistan revealed some 
Table 5 Comparison of major geographical regions (provinces) of Pakistan $(n=1,207)$

\begin{tabular}{|c|c|c|c|c|c|c|}
\hline & 1 & $\begin{array}{l}\text { Sindh, } \\
n=844\end{array}$ & $\begin{array}{l}\text { Punjab, } \\
n=277\end{array}$ & $\begin{array}{l}\text { KPK, } \\
n=70\end{array}$ & $\begin{array}{l}\text { Balochistan, } \\
n=16\end{array}$ & $p$-Value \\
\hline \multirow{2}{*}{$\begin{array}{l}\text { My institution has an online learning management system (LMS) or } \\
\text { Web site where all information about online classes is available }\end{array}$} & Mean & 2.94 & 2.46 & 3.13 & 2.94 & \multirow[t]{2}{*}{$<0.01^{\mathrm{a}}$} \\
\hline & SD & 1.156 & 1.065 & 1.141 & 1.34 & \\
\hline \multirow{2}{*}{$\begin{array}{l}\text { All key information about the course is available on the LMS or } \\
\text { institution Web site }\end{array}$} & Mean & 3.17 & 2.66 & 3.36 & 3.31 & \multirow[t]{2}{*}{$<0.01^{\text {a }}$} \\
\hline & SD & 1.14 & 1.063 & 1.13 & 1.078 & \\
\hline \multirow[t]{2}{*}{ All course readings, assignments, and lectures are available online } & Mean & 3.17 & 2.36 & 3.1 & 2.88 & \multirow[t]{2}{*}{$<0.01^{\mathrm{a}}$} \\
\hline & SD & 1.219 & 0.932 & 1.157 & 1.408 & \\
\hline \multirow{2}{*}{$\begin{array}{l}\text { Students are assisted in overcoming obstacles in accessing the classes } \\
\text { or materials }\end{array}$} & Mean & 2.95 & 2.73 & 2.73 & 3.19 & \multirow[t]{2}{*}{$<0.01^{\mathrm{a}}$} \\
\hline & SD & 1.042 & 0.968 & 1.062 & 1.109 & \\
\hline \multirow[t]{2}{*}{ Time allotted for online classes is sufficient? } & Mean & 2.39 & 2.28 & 2.23 & 2.63 & \multirow[t]{2}{*}{0.269} \\
\hline & SD & 0.974 & 0.971 & 0.904 & 1.408 & \\
\hline \multirow[t]{2}{*}{ I am able to interact with teachers during online classes } & Mean & 2.79 & 2.51 & 1.96 & 2.38 & \multirow[t]{2}{*}{$<0.001^{\mathrm{a}}$} \\
\hline & SD & 1.21 & 1.027 & 0.788 & 1.204 & \\
\hline \multirow[t]{2}{*}{ I am able to interact with teachers after online class in the Q\&A session } & Mean & 2.43 & 2.47 & 2.29 & 2.75 & \multirow[t]{2}{*}{0.297} \\
\hline & SD & 1.031 & 0.942 & 1.051 & 1.238 & \\
\hline \multirow{2}{*}{$\begin{array}{l}\text { Every individual is given a chance to participate and pitch in their ideas } \\
\text { during online classes }\end{array}$} & Mean & 2.86 & 2.52 & 2.01 & 2.81 & \multirow[t]{2}{*}{$<0.001^{\mathrm{a}}$} \\
\hline & SD & 1.218 & 0.973 & 0.771 & 1.223 & \\
\hline \multirow{2}{*}{$\begin{array}{l}\text { The teachers are well trained for online classes and are able to use the } \\
\text { Video Conferencing App with ease }\end{array}$} & Mean & 3.08 & 2.95 & 2.53 & 2.44 & \multirow[t]{2}{*}{$<0.001^{\mathrm{a}}$} \\
\hline & SD & 1.176 & 1.048 & 1.139 & 0.964 & \\
\hline \multirow[t]{2}{*}{ Attending classes from home hampers my attention and focus } & Mean & 2.55 & 2.57 & 2.49 & 3.25 & \multirow[t]{2}{*}{0.216} \\
\hline & SD & 1.194 & 1.216 & 0.989 & 1.342 & \\
\hline \multirow{2}{*}{$\begin{array}{l}\text { Online classes are equally or more informative as compared with active } \\
\text { learning in campus }\end{array}$} & Mean & 3.89 & 3.66 & 3.87 & 3.44 & \multirow[t]{2}{*}{0.09} \\
\hline & SD & 1.131 & 1.277 & 1.076 & 1.504 & \\
\hline \multirow{2}{*}{$\begin{array}{l}\text { Online learning fits in my schedules better than normal day to day } \\
\text { classes }\end{array}$} & Mean & 3.47 & 3.3 & 3.37 & 3.5 & \multirow[t]{2}{*}{0.325} \\
\hline & SD & 1.216 & 1.305 & 1.218 & 1.265 & \\
\hline \multirow{2}{*}{$\begin{array}{l}\text { Demonstration of clinical/laboratory work by the instructor during } \\
\text { online classes would help me learn in a better way }\end{array}$} & Mean & 3.41 & 3.37 & 3.34 & 3.75 & \multirow[t]{2}{*}{0.691} \\
\hline & SD & 1.346 & 1.264 & 1.202 & 0.931 & \\
\hline \multirow{2}{*}{$\begin{array}{l}\text { I would like to have these online sessions continued even after campus } \\
\text { classes have started }\end{array}$} & Mean & 3.85 & 3.55 & 3.96 & 3.56 & \multirow[t]{2}{*}{$0.035^{a}$} \\
\hline & SD & 1.177 & 1.379 & 1.069 & 1.365 & \\
\hline
\end{tabular}

Abbreviation: SD, standard deviation.

${ }^{a} p$-Value calculated by using Kruskal-Wallis test.

interesting trends as reported in - Table 5. Students of Sindh, KPK, and Balochistan were not satisfied with the quality of LMS or online resources as compared with the students of Punjab. Students were also not satisfied with the assistance they received all across Pakistan. Students from KPK and Balochistan were satisfied with teachers' training. Results show that students all across Pakistan were dissatisfied with the effectiveness of online classes as compared with active campus learning sessions (Online classes are equally or more informative as compared with active learning on-campus, mean rating: $>3, p=0.09$ )

\section{Responses of Students by Year of Study}

This important comparison revealed interesting details (-Table 6). Students of the first year reported poor 
Table 6 Comparison of responses by students all 4-year of study $(n=1,207)$

\begin{tabular}{|c|c|c|c|c|c|c|}
\hline & & $\begin{array}{l}1 \\
n=253\end{array}$ & $\begin{array}{l}2 \\
n=372\end{array}$ & $\begin{array}{l}3 \\
n=221\end{array}$ & $\begin{array}{l}4 \\
n=361\end{array}$ & p-Value \\
\hline \multirow{2}{*}{$\begin{array}{l}\text { My institution has an online learning } \\
\text { management system (LMS) or Web site } \\
\text { where all information about online classes } \\
\text { is available }\end{array}$} & Mean & 2.85 & 2.67 & 2.91 & 2.97 & \multirow[t]{2}{*}{$<0.01^{*}$} \\
\hline & SD & 1.102 & 1.135 & 1.186 & 1.177 & \\
\hline \multirow{2}{*}{$\begin{array}{l}\text { All key information about the course is } \\
\text { available on LMS or institution Web site }\end{array}$} & Mean & 3.04 & 2.89 & 3.18 & 3.2 & \multirow[t]{2}{*}{$<0.01^{*}$} \\
\hline & SD & 1.063 & 1.151 & 1.132 & 1.17 & \\
\hline \multirow{2}{*}{$\begin{array}{l}\text { All course readings, assignments and lec- } \\
\text { tures are available online }\end{array}$} & Mean & 3.23 & 2.58 & 3.15 & 3.09 & \multirow[t]{2}{*}{$<0.001^{*}$} \\
\hline & SD & 1.174 & 1.134 & 1.232 & 1.188 & \\
\hline \multirow{2}{*}{$\begin{array}{l}\text { Students are assisted in overcoming obsta- } \\
\text { cles in accessing the classes or materials }\end{array}$} & Mean & 3.05 & 2.71 & 3 & 2.91 & \multirow[t]{2}{*}{$<0.001^{*}$} \\
\hline & SD & 1.022 & 1.012 & 0.998 & 1.054 & \\
\hline \multirow[t]{2}{*}{ Time allotted for online classes is sufficient? } & Mean & 2.66 & 2.31 & 2.27 & 2.26 & \multirow[t]{2}{*}{$<0.001^{*}$} \\
\hline & SD & 1.096 & 0.957 & 0.857 & 0.937 & \\
\hline \multirow{2}{*}{$\begin{array}{l}\text { I am able to interact with teachers during } \\
\text { online classes }\end{array}$} & Mean & 3.17 & 2.64 & 2.66 & 2.38 & \multirow[t]{2}{*}{$<0.001^{*}$} \\
\hline & SD & 1.197 & 1.155 & 1.069 & 1.113 & \\
\hline \multirow{2}{*}{$\begin{array}{l}\text { I am able to interact with teachers after } \\
\text { online class in Q\& A session }\end{array}$} & Mean & 2.64 & 2.38 & 2.43 & 2.35 & \multirow[t]{2}{*}{$<0.01^{*}$} \\
\hline & SD & 1.047 & 1.034 & 0.935 & 1.007 & \\
\hline \multirow{2}{*}{$\begin{array}{l}\text { Every individual is given a chance to partic- } \\
\text { ipate and pitch in their ideas during online } \\
\text { classes }\end{array}$} & Mean & 3.3 & 2.6 & 2.68 & 2.51 & \multirow[t]{2}{*}{$<0.001^{*}$} \\
\hline & SD & 1.236 & 1.097 & 1.083 & 1.107 & \\
\hline \multirow{2}{*}{$\begin{array}{l}\text { The teachers are well trained for online } \\
\text { classes and are able to use the Video } \\
\text { Conferencing App with ease }\end{array}$} & Mean & 3.28 & 2.74 & 3.12 & 3.01 & \multirow[t]{2}{*}{$<0.001^{*}$} \\
\hline & SD & 1.09 & 1.111 & 1.171 & 1.169 & \\
\hline \multirow{2}{*}{$\begin{array}{l}\text { Attending classes from home hampers my } \\
\text { attention and focus }\end{array}$} & Mean & 2.38 & 2.58 & 2.6 & 2.64 & \multirow[t]{2}{*}{0.051} \\
\hline & SD & 1.126 & 1.165 & 1.26 & 1.212 & \\
\hline \multirow{2}{*}{$\begin{array}{l}\text { Online classes are equally or more inform- } \\
\text { ative as compared with active learning in } \\
\text { campus }\end{array}$} & Mean & 4.14 & 3.65 & 3.93 & 3.72 & \multirow[t]{2}{*}{$<0.01^{*}$} \\
\hline & SD & 0.935 & 1.258 & 1.12 & 1.214 & \\
\hline \multirow{2}{*}{$\begin{array}{l}\text { Online learning fits in my schedules better } \\
\text { than normal day to day classes }\end{array}$} & Mean & 3.68 & 3.26 & 3.47 & 3.38 & \multirow[t]{2}{*}{$<0.01^{*}$} \\
\hline & SD & 1.125 & 1.307 & 1.249 & 1.209 & \\
\hline \multirow{2}{*}{$\begin{array}{l}\text { Demonstration of clinical/laboratory work } \\
\text { by the instructor during online classes } \\
\text { would help me learn in a better way }\end{array}$} & Mean & 3.47 & 3.32 & 3.46 & 3.41 & \multirow[t]{2}{*}{0.343} \\
\hline & SD & 1.277 & 1.252 & 1.302 & 1.408 & \\
\hline \multirow{2}{*}{$\begin{array}{l}\text { I would like to have these online sessions } \\
\text { continued even after campus classes have } \\
\text { started }\end{array}$} & Mean & 3.99 & 3.63 & 3.93 & 3.7 & \multirow[t]{2}{*}{$<0.01^{*}$} \\
\hline & SD & 1.084 & 1.285 & 1.12 & 1.3 & \\
\hline
\end{tabular}

Abbreviation: SD, standard deviation.

${ }^{*} p$-Value calculated by using Kruskal-Wallis test.

interaction with teachers as compared with the students of other years (mean rating: $3.17 \pm 1.197, p<0.001$ ). Similarly, the students of the first year also strongly disagreed with the effectiveness of online classes (mean rating: $4.14 \pm 0.935$ ) as compared with students of other years.

\section{Discussion}

The COVID-19 pandemic has forced the educational institutes around the world to adapt and embrace online teaching platforms..$^{20}$ The current study is the first nation-wide survey conducted on the effectiveness of online teaching among undergraduate dental students of Pakistan. Before COVID-19, the country had a rudimentary online education presence; however, after the national shutdown of all daily activities, the educational institutes all over the country were left with no other option but to familiarize themselves with different online learning modalities and forums in the matter of a fortnight. ${ }^{21}$ To overcome these difficulties, the Higher Education Commission (HEC) of Pakistan penned down a six-point preparedness agenda (1. University Readiness, 2. Faculty Readiness, 3. Course Readiness, 4. Library Readiness, 5. Technology Readiness, 6. Student Readiness) to aid in guiding the educational institutes for appropriate and effective delivery of online teaching sessions for the continuation of academic endeavors. ${ }^{22}$ The current survey was conducted by keeping the proposed six aspects of online readiness agenda as part of the questionnaire. The objective was to observe and 
report the significant obstacles faced by the dental students of Pakistan with regard to the somewhat different and sudden shift in the mode of learning.

Results of the present survey revealed that the majority of the students rated their internet connection from average to poor. Similar findings were reported by previous studies conducted on determining the key factors associated with student satisfaction in distance learning programs of Pakistan. ${ }^{23,24}$ These studies further reported that respondents from all over the country were generally dissatisfied with their internet service provider and demanded fast internet speed and high broadband connections to facilitate and improve their online learning experience. ${ }^{23,24}$ The present survey also showed that most students reported unimpeded electric supply during the period of their online sessions. This is an important observation since it has been reported that inadequate electric supply is one of the factors associated with stress among medical students that may lead to poor learning performance. ${ }^{25}$ Although in the current survey a high percentage of participants responded with satisfaction to the availability of electric supply during the spring season; power outages are frequent in summer season. The possibility of frequent power outages in hot summer weather coupled with an average performing internet connection may prove to be two most noteworthy limiting factors in determining the future efficacy of online teaching programs in Pakistan.

In this survey, smartphones were rated highest among the devices used by the respondents for attending online lectures and social media was recorded as the most used mode for notification of class schedule. These results are in accordance with other studies where dental and medical students have shown positive learning attitudes using smartphone technology. ${ }^{26-28}$ Studies have reported that portability, time management, and easy access to data are some of the main reasons listed by the medical and dental students favoring increased usage of smartphones and mobile applications for e-learning. ${ }^{26,29}$ With the presence of a multitude of research evidence supporting the use of smartphones and social media technology for educational purposes, many authors recommend designing programs, materials, and activities that are compatible with smartphone technology, thereby integrating this diverse learning approach as a part of the official teaching curriculum. ${ }^{29,30}$

Results of our present survey showed an overall significant contrast between public and private dental school sectors. It was observed that public school students showed an overall higher dissatisfaction response rate to various features of virtual learning in comparison to private school students. This indicates that private dental institutes were better able to answer the quick and urgent call of online learning and establishment of their institutional-based online teaching forums and curriculums. A high dissatisfaction response values were recorded among public school students' vis-à-vis institutional LMS system, the online availability of lecture content, their ability to interact with teachers during online classes, and overcoming obstacles in accessing classes and supplemental material.7 Several authors have suggested that virtual educational programs require intricate hardware and software infrastructure that allows easy navigation and access to content tools for effective learning. ${ }^{13,31}$ This could explain the better performance of private dental schools in the development of an online teaching platform, as these institutes have more resources-both financial and in manpower to undertake this laborious endeavor.

On the other hand, students of both educational sectors expressed an overall dissatisfaction toward teachers' ability to deliver online lectures with ease. This finding can be credited to the urgency and haste with which the teachers were required to acclimate themselves with online learning technology. This observation resonates with other authors of previous studies who concluded that creating effective, innovative, and educational online content is a challenging and time-consuming exercise that will require a necessary transitional period of training and adaptation. ${ }^{32,33}$ We recommend that this pressing student concern is addressed in time as teachers can be encouraged to enroll into online training courses and programs, which will give them the necessary tools needed to become acquainted with different aspects of virtual learning modalities. This will aid the dental educators in improving the quality of online sessions currently being delivered.

The present survey also analyzed students' responses according to their year of dental education. It was observed that out of the 4 years of dental school, students currently enrolled in first year of dentistry program found it more challenging to adjust to online learning compared with other year dental students. These results are in contrast to previous studies where students in pre-clinical years (first and second years) of dental schools of Australia, Saudi Arabia, and India showed a more positive response toward online learning in comparison to their clinical years (third and fourth years).,12,34 Results of the present survey also revealed that regardless of the year of dentistry program, students all over the country voiced an overall dissatisfaction toward online classes in general. Students agreed that online classes interfere with their attention and focus on learning. Majority of the students voiced disagreement when asked if online classes proved more informative, and if the demonstrations of clinical or laboratory work were better explained when compared with conventional face-to-face lectures and demonstrations. Additionally, the majority of the students disagreed with the continuation of online sessions after fully resuming normal campus functions. These observations are supported by previous studies where the vast majority of dental and medical students still prefer conventional methods of teaching and are more comfortable learning from textbooks and lectures delivered in person..$^{28,29}$ On the contrary, some studies have reported that students prefer a blended pedagogy approach in which conventional learning sessions can be combined with online recorded lectures to deliver supplemental coursework materials and assignments to augment knowledge and learning experience of students. ${ }^{13,27,35}$

It can be conclusively accepted that the current pandemic has irrefutably exposed the limitations associated with the adaptation of online teaching facilities in dental schools 
throughout the world. ${ }^{33}$ The current pandemic climate calls for a collaborative, harmonized, and mutual global effort to establish effective practice policies for online pedagogy approach. As online teaching remains a fairly new concept in Pakistan, considerable efforts need to be made in relation to finding successful and effective teaching solutions that can address student concerns that prove to be a barrier and hindrance toward effective online learning experience. ${ }^{18,28}$

We suggest having a virtual learning environment (VLE) compatible with smartphones, and the dental colleges and universities should be able to provide internet wi-fi devices to the students. There were different schemes to distribute laptops and wi-fi devices to the merit student by the HEC, which helped financially unstable students. Also, online libraries, research journals, and academic videos should be accessible to the students to groom their dental basics and clinical knowledge. Collaborative dental academic videos by dental schools globally should be available to students to enhance their online learning experience. It is an entirely new challenge for the dental faculty of Pakistan, but still they managed to run these online dental education programs nation-wide in such a short period by preparing themselves and the students to be in line among the dental students globally.

The limitation of the present survey includes acquiring an unequal amount of data from all four provinces of Pakistan, and this might be because many dental institutes were not conducting online classes during the month of April when the data was being collected. Another limitation of the study is the teachers' training capabilities to conduct online classes adequately were evaluated according to students' perception. Hence, this study does not give a true representation of whether the teachers were professionally trained by the institutes for conduction of e-classes or not.

\section{Conclusions}

The present study is the first nation-wide survey performed to explore the perceptions of undergraduate dental students toward the effectiveness of online teaching in the midst of the current COVID pandemic. Results of our study showed that dental students from all over Pakistan expressed dissatisfaction to various components of online teaching sessions. This is understandable as online teaching is a modernistic educational approach adopted by the country in haste to combat the current lockdown, in hopes of continuing academic endeavors. Although considerable efforts have been made toward the creation of VLE by various universities under the guidance of HEC Pakistan, this process is still in its infancy period. Migrating from a traditional face-to-face teaching approach to a fully functional virtual educational system will require time and expertise. Dental universities would need to invest in professional development programs for the faculty and continuously adapt to improve online teaching content. Findings from the present nation-wide survey will help in better understanding of the obstacles faced by the students concerning online teaching. This, in turn, can guide the dental and medical universities to establish an effective and productive online teaching platform centered on improving the learning experience of students.

\section{Conflict of Interest}

None declared.

\section{References}

1 Mukhtar K, Javed K, Arooj M, Sethi A. Advantages, limitations and recommendations for online learning during COVID-19 pandemic era. Pak J Med Sci 2020;36(COVID19-S4): S27-S31

2 Muljana PS, Luo T. Factors contributing to student retention in online learning and recommended strategies for improvement: a systematic literature review. J Inf Technol Educ 2019;18:19-57

3 Al-Saleh SA, Al-Madi EM, Al-Angari NS, Al-Shehri HA, Shukri MM. Survey of perceived stress-inducing problems among dental students, Saudi Arabia. Saudi Dent J 2010;22(2):83-88

4 Linjawi AI, Alfadda LS. Students' perception, attitudes, and readiness toward online learning in dental education in Saudi Arabia: a cohort study. Adv Med Educ Pract 2018;9:855-863

5 Schönwetter DJ, Reynolds PA, Eaton KA, De Vries J. Online learning in dentistry: an overview of the future direction for dental education. J Oral Rehabil 2010;37(12):927-940

6 Alghamdi SR, Bayaga A. Use and attitude towards Learning Management Systems (LMS) in Saudi Arabian universities. Eurasia J Math Sci Technol Educ 2016;12(9):2309-2330

7 Alenezi A. Barriers to participation in learning management systems in Saudi Arabian universities. Educ Res Int 2018;201810.1155/2018/9085914

8 Hamutoglu NB, Gemikonakli O, Duman I, Kirksekiz A, Kiyici M. Evaluating students experiences using a virtual learning environment: satisfaction and preferences. Educ Technol Res Dev 2020;68(1):437-462

9 Pahinis K, Stokes CW, Walsh TF, Tsitrou E, Cannavina G. A blended learning course taught to different groups of learners in a dental school: follow-up evaluation. J Dent Educ 2008;72(9):1048-1057

10 Al Raisi H, Dummer PMH, Vianna ME. How is Endodontics taught? A survey to evaluate undergraduate endodontic teaching in dental schools within the United Kingdom. Int Endod J 2019;52(7):1077-1085

11 Iyer P, Aziz K, Ojcius DM. Impact of COVID-19 on dental education in the United States. J Dent Educ 2020;84(6):718-722

12 Stormon N, Ford PJ, Eley DS. DREEM-ing of dentistry: students' perception of the academic learning environment in Australia. Eur J Dent Educ 2019;23(1):35-41

13 Asiry MA. Dental students' perceptions of an online learning. Saudi Dent J 2017;29(4):167-170

14 Moazami F, Bahrampour E, Azar MR, Jahedi F, Moattari M. Comparing two methods of education (virtual versus traditional) on learning of Iranian dental students: a post-test only design study. BMC Med Educ 2014;14(1): 4510.1186/1472-6920-14-45

15 Reynolds PA, Rice S, Uddin M. Online learning in dentistry: the changes in undergraduate perceptions and attitudes over a four year period. Br Dent J 2007;203(7):419-423

16 Morton CE, Saleh SN, Smith SF, et al. Blended learning: How can we optimise undergraduate student engagement?. BMC Med Educ 2016;16:195 doi:10.1186/s12909-016-0716-z

17 Memon AR, Rathore FA. Moodle and Online Learning in Pakistani Medical Universities: an opportunity worth exploring in higher education and research. J Pak Med Assoc 2018;68(7):1076-1078 
18 Baig QA, Abbas Zaidi SJ, Alam BF. Perceptions of dental faculty and students of E-learning and its application in a public sector Dental College in Karachi, Pakistan. J Pak Med Assoc 2019;69(9):1320-1325

19 Ahmed MA, Jouhar R, Ahmed N, et al. Fear and practice modifications among dentists to combat novel coronavirus disease (COVID-19) outbreak. Int J Environ Res Public Health 2020;17(8):2821 doi:10.3390/ijerph17082821

20 Wu DT, Wu KY, Nguyen TT, Tran SD. The impact of COVID-19 on dental education in North America-Where do we go next?. Eur J Dent Educ 2020;24(4):825-827 doi:10.1111/eje.12561

21 Dhawan S. Online learning: a panacea in the time of COVID-19 crisis. J Educ Technol Syst 2020;49(1):5-22

22 HEC COVID-19 Policy Papers Policy Guidance Note 5: Online Readiness.https://www.hec.gov.pk/english/HECAnnouncements/ Documents/nCoVirus/Covid-19-Policy-Guidance-No.5Online\%20Readiness.pdf. Accessed on June 2, 2020.

23 Ali A, Ramay MI, Shahzad M. Key factors for determining student satisfaction in distance learning courses: a study of Allama Iqbal Open University (AIOU) Islamabad, Pakistan. Turkish Online J Distance Educ 2011;12(2):114-127

24 Khan SA, Khan AA, Bhatti R. Internet access, use and gratification among university students: a case study of the Islamia University of Bahawalpur, Pakistan. Chin Librariansh Int Electron J 2011:1;32:1-4

25 Qamar K, Khan NS, Bashir Kiani MR. Factors associated with stress among medical students. J Pak Med Assoc 2015;65(7): 753-755

26 Suner A, Yilmaz Y, Pişkin B. Mobile learning in dentistry: usage habits, attitudes and perceptions of undergraduate students. PeerJ 2019;7:e7391 doi:10.7717/peerj.7391
27 Hamilton LA, Franks A, Heidel RE, McDonough SL, Suda KJ. Assessing the Value of Online Learning and Social Media in Pharmacy Education. Am J Pharm Educ 2016;80(6):97 doi:10.5688/ajpe80697

28 Abbasi S, Ayoob T, Malik A, Memon SI. Perceptions of students regarding E-learning during Covid-19 at a private medical college. Pak J Med Sci 2020;36(COVID19-S4):S57-S61 doi:10.12669/pjms.36.COVID19-S4.2766

29 Bansal S, Sahadevan DC, Mahesh S, Aneja PS, Aneja M. Smartphones-help or hindrance in advancing medical/dental education. Orig Res Artic J Evol Med Dent Sci. 2020;9(1):10-13

30 Rung A, Warnke F, Mattheos N. Investigating the use of smartphones for learning purposes by Australian dental students. JMIR Mhealth Uhealth 2014;2(2):e2010.2196/mhealth.3120

31 FitzPatrick T, Key success factors of elearning in education: A professional development model to evaluate and support elearning. US-China Education Review A 2012;2(9):789-795 doi:10.17265/2161-623X/2012.09A.004

32 Dias da Silva MA, Pereira AC, Walmsley AD. The availability of open-access videos offered by dental schools. Eur J Dent Educ 2019;23(4):522-526

33 Crawford J, Butler-Henderson K, Rodolph J, et al. Journal of Applied Learning \& Teaching COVID-19 : 20 countries ' higher education intra-period digital pedagogy responses. J Appl Learn Teach 2020;3(1):1-20

34 Tangade PS, Mathur A, Gupta R, Chaudhary S. Assessment of stress level among dental school students: an Indian outlook. Dent Res J (Isfahan) 2011;8(2):95-101

35 Schönwetter D, Reynolds P. Discovering online learning barriers: survey of health educational stakeholders in dentistry. Eur J Dent Educ 2013;17(1):e126-e135 